\title{
Delayed rupture of a pseudoaneurysm in the brachial artery of a burn reconstruction patient
}

\author{
Jun Yong Lee, Hyeri Kim, Ho Kwon and Sung-No Jung*
}

\begin{abstract}
A brachial artery pseudoaneurysm is a rare but serious condition that can be limb threatening. A number of reports have found that it may be the result of damage to the blood vessels around the brachial artery, either directly or indirectly, due to trauma or systemic diseases. We present our experience of delayed pseudoaneurysm rupture of the brachial artery in a rehabilitation patient with burns of the upper extremity who underwent fasciotomy and musculocutaneous flap coverage. We also provide a review of the brachial artery pseudoaneurysm.
\end{abstract}

Keywords: Pseudoaneurysm, Brachial artery, Burn, Reconstruction

\section{Introduction}

A pseudoaneurysm of the peripheral artery is very rare and is generally a late sequela of trauma, iatrogenic injury, and general illness. It is more infrequent in the upper limb vasculature than in the lower limb vasculature. Although there are many reported causes of brachial artery pseudoaneurysms, to our knowledge, this is the first report of delayed rupture of a brachial artery pseudoaneurysm during the rehabilitation of a patient with burns of the upper extremity who underwent fasciotomy and musculocutaneous flap coverage. We also present a review of the brachial artery pseudoaneurysm.

\section{Presentation of case}

A 26-year old male patient presented to the hospital with wound dehiscence and oozing of the left axilla that had commenced two days earlier while undergoing rehabilitative therapy for postburn joint ankylosis and brachial plexus palsy of the upper extremity (Figure 1). According to the patient's history, he had undergone escharectomy and latissimus dorsi musculocutaneous flap coverage of a neurovascular bundle exposed in the medial upper arm due to a contact burn of the left upper extremity six months earlier, in addition to a splitthickness skin graft for a lesion (Figure 2). At the time of the hospital visit, the patient's blood pressure was

\footnotetext{
* Correspondence: jsn7190@catholic.ac.kr

Department of Plastic and Reconstructive Surgery, Uijeongbu St. Mary's Hospital, The Catholic University of Korea, 271 Cheonbo-ro, Uijeongbu-si, Gyeonggi-do 480-717, Korea
}

$130 / 74 \mathrm{mmHg}$, and his heart rate was $98 \mathrm{bpm}$. The hemoglobin value was $12.8 \mathrm{~g} / \mathrm{dl}$. The examination revealed no other specific findings. The wound was approximately $1 \times 1 \mathrm{~cm}$ wide, with bleeding in an oozing pattern. Distal pulsation and circulation had been maintained. Under the assumption that wound dehiscence had occurred during the rehabilitative treatment, a moderate compression gauze dressing was applied. The wound gradually healed, but wound rupture occurred again at the site of the posterior axilla on day 14 of hospitalization. The new site of wound dehiscence was due to a hematoma, which was accompanied by profuse bleeding. A gauze compression bandage was applied again, and a computed tomography angiography (CTA) was conducted. The CTA images revealed a pseudoaneurysm in the brachial artery (Figure 3). Due to the profuse bleeding from wound, the patient's blood pressure was decreased to $90 / 50 \mathrm{mmHg}$, and the heart rate was increased up to $108 \mathrm{bpm}$. The hemoglobin value was also dropped to $8.2 \mathrm{~g} / \mathrm{dl}$. The patient underwent immediate surgical exploration and the pseudoaneurysm was approached through the marginal side of the previously performed latissimus dorsi musculocutaneous flap. The blood-pumping ruptured brachial artery pseudoaneurysm was identified by elevating the flap. The pseudoaneurysm originated from a linear, slit-like longitudinal disruption of the brachial artery (Figure 4). The aneurysmal sac was excised at its base, and the slit-like brachial artery defect was closed with 6-0 Prolene (polyprophylene suture, Ethicon Inc., New Brunswick, NJ, 


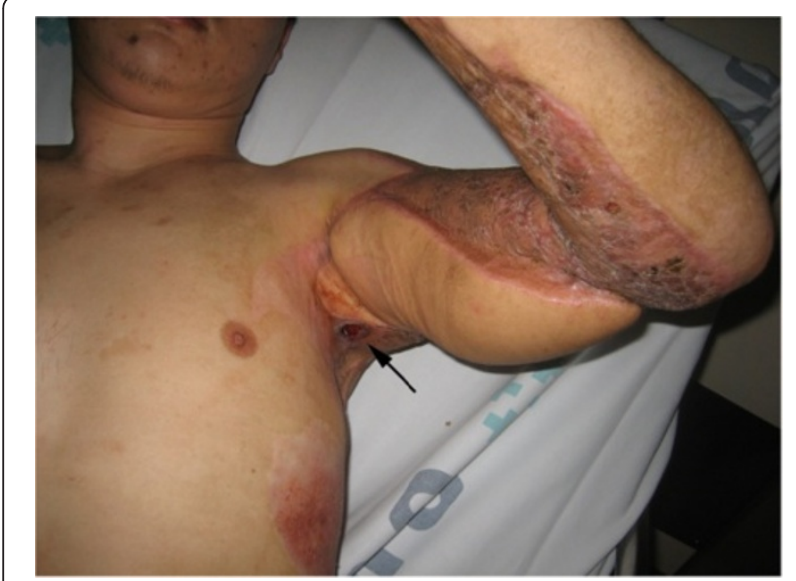

Figure 1 Initial presentation of the patient. A round ulcerated wound was noted at the posterior axilla.

USA) sutures. The brachial artery and accompanying median and musculocutaneous nerves showed fibrotic adhesion to the surrounding muscle and fascia. The tethering adhesions were carefully removed in order to recover neurovascular bundle gliding. The wound was closed with replacing the elevated flap after placing an Jackson-Pratt drain. After the removal of the pseudoaneurysm, the distal circulation was maintained. The patient recieved three packs of packed red blood cells postoperatively and the patient's vital sign was stabilized again. A CTA taken on postoperative day ten confirmed that the pseudoaneurysm had disappeared and that the distal circulation was being maintained (Figure 5). During one year of postoperative follow up, there was no recurrence of distal circulation impairment or pseudoaneurysms.

\section{Discussion}

An aneurysm is defined as a permanent localized dilatation of an artery with at least a $50 \%$ increase in its diameter compared with the expected normal diameter [1]. Aneurysms occurring in the upper extremities can be classified largely into false types and true types. False aneurysms are also known as pseudoaneurysms. They can occur after traumatic penetration of the vessel, causing subsequent hemorrhage and extravasation. The hematoma that forms leads to fibrosis and recanalization of soft tissues. False vessels newly formed in this way resemble true vessels but are characterized by a lining of endothelial cells. True arterial aneurysms are formed when the vessel is damaged, which can enable gradual vasodilation. Unlike the sac shape of true aneurysms, pseudoaneurysms have a uniform shape and form easily at a site of repetitive trauma.

A brachial artery aneurysm usually presents as a pseudoaneurysm and rarely as a true aneurysm [2]. Its etiology can be largely classified into three types: congenital [3]; association with systemic disease, such as Ehlers-Danlos syndrome [4], Menkes disease [5], mycotic aneurysm [6,7], polyarteritis nodosa [8], giant cell arteritis [9], Behcet disease [10], Kawasaki's disease [11], neurofibromatosis [12], and osteochondroma [13]; and sequelae of trauma, including brachial artery arteriography [14], crutch use [15], humerus fracture [16], supracondylar fracture [17], iatrogenic injury [18], blunt trauma [19], drug abuse [20], and missile injury [21]. The clinical features of brachial artery pseudoaneurysm by etiology are summarized in Table 1 .

The brachial artery pseudoaneurysm usually develop slowly. It took days to months, even years to develop symptoms or be detected clinically. A brachial artery pseudoaneurysm often presents with erythema and induration, together with an expanding, painful mass. It is sometimes accompanied by a thrill or an audible bruit, decreased temperature, cyanosis, loss of pulsation, and paresthesia upon nerve compression of the distal extremity [22]. Various diagnostic methods can be used, including arterial Doppler ultrasonography, angiography,

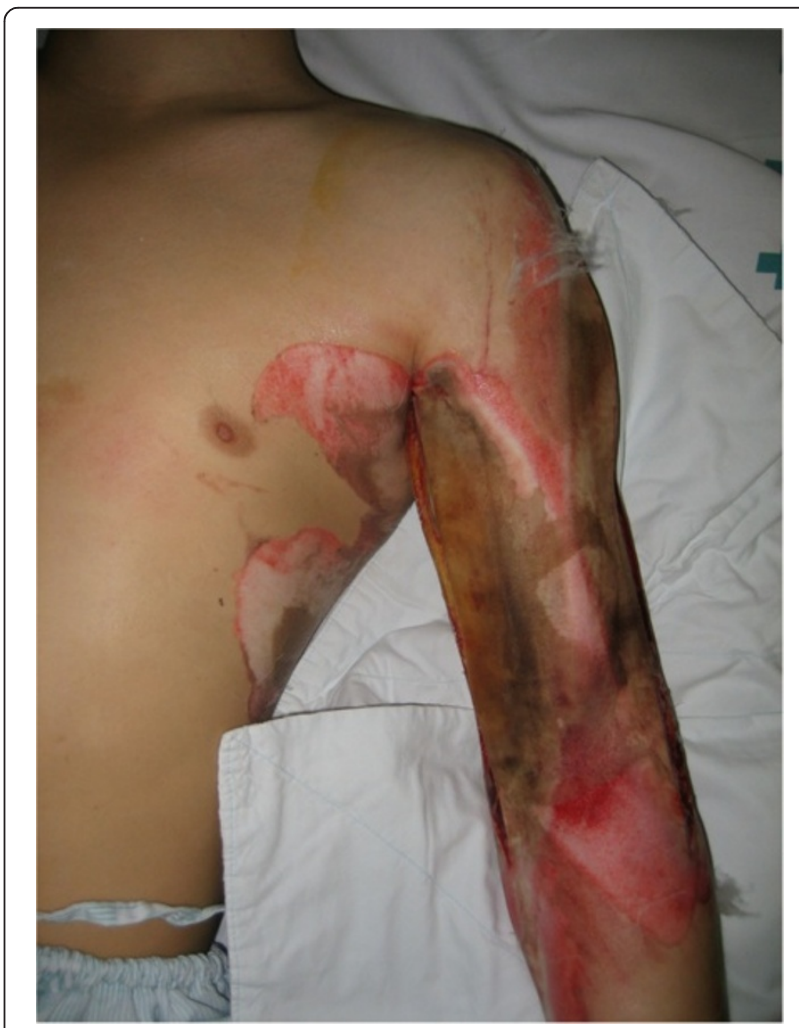

Figure 2 Clinical image at the time of the contact burn six months earlier. At the time of the contact burn six months earlier, the patient had undergone immediate fasciotomy for a wound at the medial and lateral aspect of the upper arm. The exposed neurovascular bundle was covered with a latissimus dorsi musculocutaneous flap, and the rest of the lesion was covered with a split-thickness skin graft. 


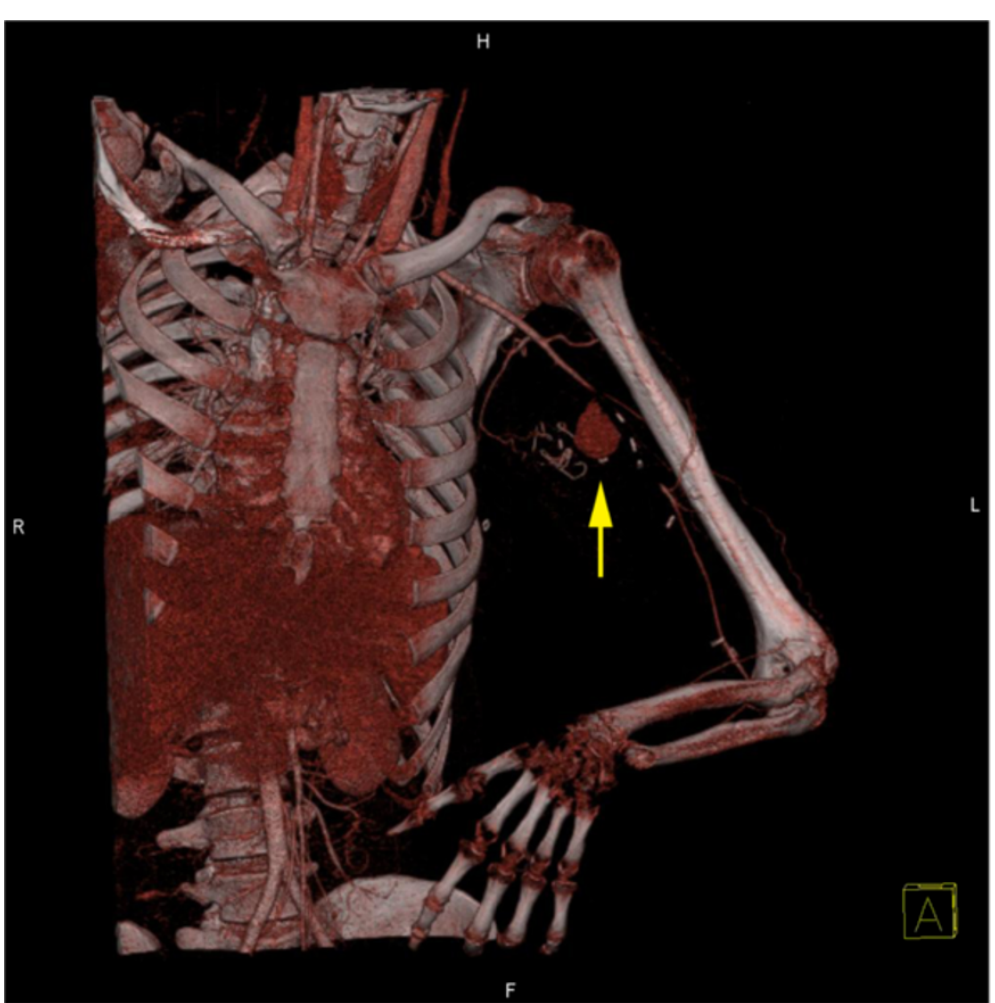

Figure 3 Preoperative three-dimensionally reconstructed angio CT scan. Three-dimensionally reconstructed angio CT scan. A pseudoaneurysm in the left brachial artery was noted.

contrast-enhanced computed tomography (CT), and magnetic resonance imaging (MRI). Although selective arteriography is accepted as the gold standard [23], high-resolution duplex ultrasonography is faster, more cost effective, and more readily available in the emergency department [24].

Very rarely, the presence of a thromboembolism in the aneurysm can result in terminal ischemia, gangrene, and amputation [10]. In such cases, only early diagnosis and treatment can prevent progression to major disability. The treatment of brachial artery pseudoaneurysm depends on the location, size, pathogenesis, and accessibility of the pseudoaneurysm [25]. Surgical methods (ligation, resection and reanastomosis or vein graft interpositioning), endovascular methods (endovascular stent-graft implantation, embolization of sac, embolization of distal and proximal arterial segments), external compression (USguided), and percutaneous thrombin injection can be used for treatment. Due to the emerging technical evolution of the endovascular intervention, which prevents bleeding and invasive procedure, the need for surgical intervention has decreased. However, there are surgical indications that cannot be substituted with other less invasive methods: rapidly expanding pseudoaneurysm, infected pseudoaneurysm, distal ischemia caused by local pressure by the pseudoaneurysm, neuropathy caused by local pressure, failure of percutaneous treatment, and ischemic soft tissues and skin caused by local pressure [26]. Although a single small pseudoaneurysm that is located distal to the brachial bifurcation can be ligated [25], surgical excision with arterial reconstruction is the standard treatment. The arterial continuity should be restored with end-to-end anastomosis or a venous interposition graft [20,27].

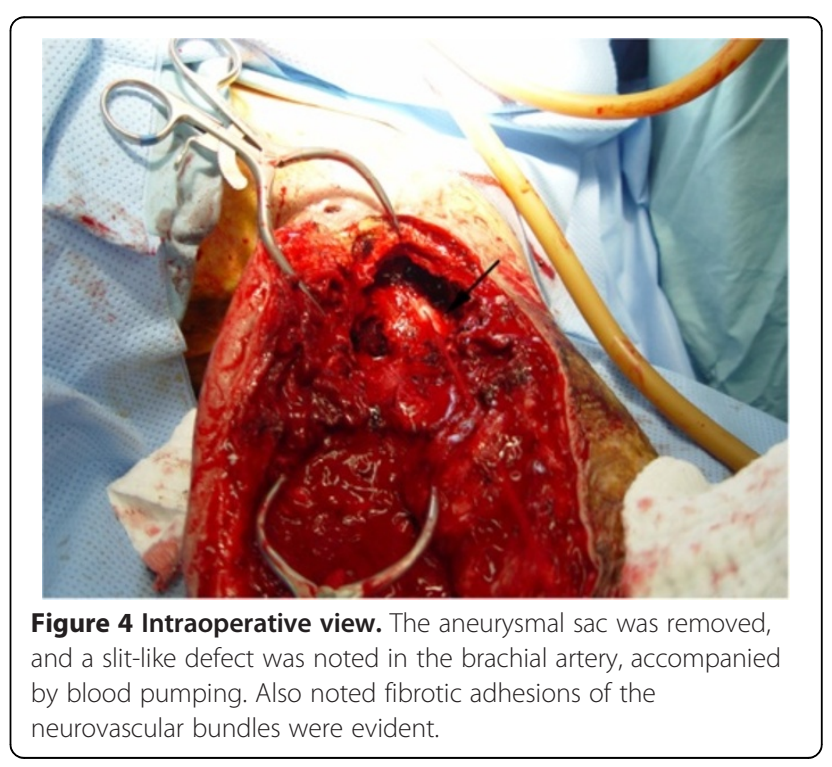




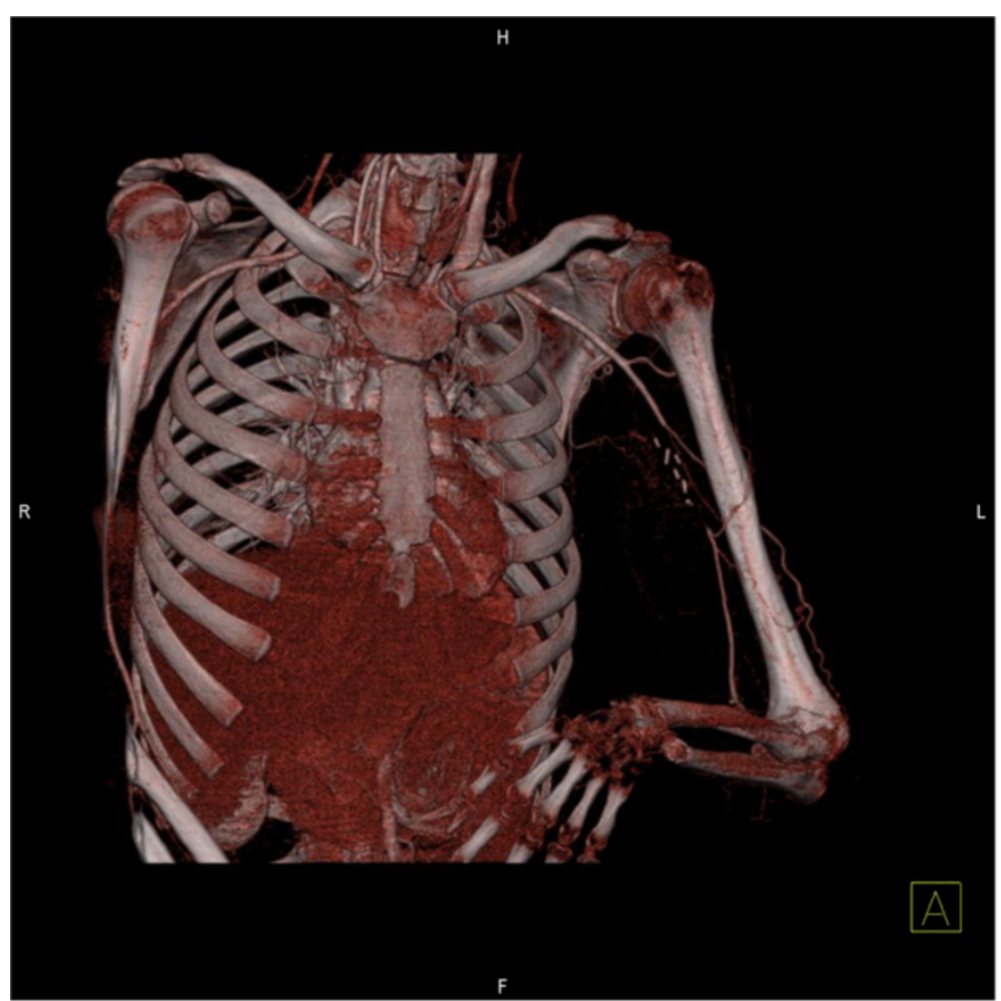

Figure 5 Ten days postoperative three-dimensionally reconstructed angio CT scan. Postoperative view of the three-dimensionally reconstructed angio CT scan 10 days after the removal of the pseudoaneurysm. Intact distal flows were noted.

Endovascular stent-grafts implantation is a minimally invasive intervention with a high success rate. However, the high cost of the device, luminal stenosis, and long-term complications, such as device failure, should be considered $[28,29]$. Embolization of the sac is indicated when the sac is small and the pseudoaneurysm does not disturb the distal circulation. Embolization of the distal and proximal arterial segments is only indicated if collateral circulation is sufficient [25]. US-guided compression was first introduced as a treatment of postangiographic femoral artery injury and also applied for treatment of a brachial artery pseudoaneurysm [30,31]. However, there are limitations, such as a long procedural time, patient discomfort, and lower effectiveness with an anticoagulated patient. When there is infection, coexisting large hematomas with impending compartment syndrome, limb ischemia, skin ischemia, excessive patient discomfort, and unsuitable anatomy, US-guided compression is contraindicated [26]. Percutaneous thrombin injection is performed under US-guide and also conducted with the aid of intraluminal balloon occlusion $[32,33]$. This has shown a high success rate and a low recurrence and complication rate. However, there have been several reports of complications, such as distal embolization, anaphylaxis, abscess formation, and pseudoaneurysm rupture. There can be complications including median nerve traction due to postoperative adhesion [24], true aneurysm formation [34] and Volkmann's ischemic contracture [35].

This case did not show the generally observed symptoms of a pseudoaneurysm: swelling, thrill, and a masslike lesion. A brachial artery pseudoaneurysm was not suspected at first because the patient had visited the hospital with wound dehiscence, accompanied by oozing as the main complaint. It is difficult to perform an accurate physical examination after burn wound reconstruction because the surrounding tissue hardens as a result of fibrosis. This fibrosis of the surrounding tissues also helped to prevent continuous enlargement of the pseudoaneurysm in the present case. The pseudoaneurysm in this patient is likely to have formed gradually due to partial damage of the brachial artery wall during burn rehabilitation when the soft tissues adhered to the blood vessel tract, and due to burn-induced blood vessel injuries. As shown in Figure 4, the pseudoaneurysm originated from a slit-like opening of the brachial artery. And the surrounding neurovascular bundle sheath and muscles had fibrosis as a consequence of the severe burn injury. In a preoperative computed tomography angiography, shown in Figure 3, collateral circulation was noted. Considering the fibrotic surrounding tissue quality and existing collateral circulation, we excised the pseudoaneurysm sac and repaired the slit-like vascular defect with sutures primarily, 
Table 1 A summary of reported etiology of brachial artery aneurysm

\begin{tabular}{|c|c|c|c|c|c|c|c|}
\hline Etiology & Sex/Age & Onset & Symptom \& sign & $\begin{array}{l}\text { Diagnostic } \\
\text { modality }\end{array}$ & Treatment & Complications & Reference \\
\hline
\end{tabular}

\section{True aneurysm}

$F / 77$

2 years ago

Painless swelling

CT angiography

Resection and saphenous No vein graft

Pseudoaneurysm

\begin{tabular}{|c|c|c|c|c|c|c|c|}
\hline Congenital & $\mathrm{M} / 0$ & Congenital & $\begin{array}{l}\text { Small, non-tender } \\
\text { swelling }\end{array}$ & Arteriography & $\begin{array}{l}\text { Resection and end-to-end } \\
\text { anastomosis }\end{array}$ & No & [3] \\
\hline \multicolumn{8}{|c|}{ Association with systemic disease } \\
\hline $\begin{array}{l}\text { Ehlers-Danlos } \\
\text { syndrome }\end{array}$ & $M / 11$ & N/A & Pulsating mass & Color-Doppler & Ligation and Excision & N/A & [4] \\
\hline $\begin{array}{l}\text { Menkes } \\
\text { disease }\end{array}$ & $\mathrm{F} / 10 \mathrm{~m}$ & 10 months ago & Pulsating mass & Ultrasonography & Ligation and Excision & No & [5] \\
\hline \multirow[t]{2}{*}{$\begin{array}{l}\text { Mycotic } \\
\text { aneurysm }\end{array}$} & $F / 29$ & $\begin{array}{l}9 \text { days after } \\
\text { catheterization }\end{array}$ & Pain, Swelling & $\begin{array}{l}\text { Surgical } \\
\text { Exploration }\end{array}$ & Wide excision & Muscle atrophy & {$[6]$} \\
\hline & $\mathrm{M} / 20$ & $\begin{array}{l}26 \text { days after } \\
\text { Penicillin } \\
\text { injection }\end{array}$ & $\begin{array}{l}\text { Tenderness, swelling, } \\
\text { marked induration }\end{array}$ & $\begin{array}{l}\text { Oscillometer } \\
\text { and Surgical } \\
\text { Exploration }\end{array}$ & Ligation and Excision & $\begin{array}{l}\text { Slight weakness } \\
\text { and numbness }\end{array}$ & {$[7]$} \\
\hline $\begin{array}{l}\text { Periarteritis } \\
\text { nodosa }\end{array}$ & $F / 16 w$ & $\begin{array}{l}6 \text { weeks } \\
\text { after fever }\end{array}$ & $\begin{array}{l}\text { Bilateral pulsating mass, } \\
\text { loss of radial pulse }\end{array}$ & Arteriography & Prednisone, Observation & $\begin{array}{l}\text { No (Size } \\
\text { unchanged) }\end{array}$ & [8] \\
\hline $\begin{array}{l}\text { Giant cell } \\
\text { arteritis }\end{array}$ & $M / 8$ & $\begin{array}{l}2 \text { months } \\
\text { after flu }\end{array}$ & Pulsatile mass & $\begin{array}{l}\text { Surgical } \\
\text { Exploration }\end{array}$ & $\begin{array}{l}\text { Resection and saphenous } \\
\text { vein graft }\end{array}$ & No & [9] \\
\hline $\begin{array}{l}\text { Behcet } \\
\text { disease }\end{array}$ & $M / 18$ & $\begin{array}{l}9 \text { months after } \\
\text { oral ulceration }\end{array}$ & $\begin{array}{l}\text { Non-specific, multiple } \\
\text { oral ulcer multiple } \\
\text { papule on forearm }\end{array}$ & Angiography & $\begin{array}{l}\text { Azathioprine, } \\
\text { Prednisolone }\end{array}$ & $\begin{array}{l}\text { Recurred after } \\
18 \text { months later }\end{array}$ & [10] \\
\hline $\begin{array}{l}\text { Kawasaki's } \\
\text { disease }\end{array}$ & $\mathrm{M} / 6 \mathrm{~m}$ & N/A & Axillary mass & Arteriography & Resection and vein graft & No & [11] \\
\hline Neurofibromatosis & $\mathrm{F} / 30$ & IUP 34 weeks & $\begin{array}{l}\text { Arm pain, enlargement } \\
\text { of elbow and forearm }\end{array}$ & Arteriography & $\begin{array}{l}\text { Saphenous vein graft/ } \\
\text { Transhumeral amputation }\end{array}$ & $\begin{array}{l}\text { Decreased } \\
\text { arm function }\end{array}$ & [12] \\
\hline \multirow[t]{2}{*}{ Osteochondroma } & $M / 17$ & 4 years ago & $\begin{array}{l}\text { Swelling, pain, } \\
\text { paresthesia }\end{array}$ & $\begin{array}{l}\text { Surgical } \\
\text { exploration }\end{array}$ & $\begin{array}{l}\text { Resection and saphenous } \\
\text { vein graft }\end{array}$ & No & [13] \\
\hline & $M / 25$ & Sudden onset & $\begin{array}{l}\text { Pain, swelling, } \\
\text { hematoma }\end{array}$ & $\begin{array}{l}\text { Arteriography, } \\
\text { Ultrasonography }\end{array}$ & $\begin{array}{l}\text { Resection and saphenous } \\
\text { vein graft }\end{array}$ & No & \\
\hline \multicolumn{8}{|l|}{ Sequela of trauma } \\
\hline $\begin{array}{l}\text { Brachial artery } \\
\text { arteriography }\end{array}$ & $M / 40-50$ & $\begin{array}{l}2-3 \text { weeks after } \\
\text { procedure }\end{array}$ & $\begin{array}{l}\text { Increasing small mass, } \\
\text { pulsating mass }\end{array}$ & $\begin{array}{l}\text { Surgical } \\
\text { Exploration }\end{array}$ & $\begin{array}{l}\text { Resection and primary } \\
\text { repair }\end{array}$ & No & [14] \\
\hline Crutch use & $M / 76$ & 1 year ago & $\begin{array}{l}\text { Palpable mass, absent } \\
\text { distal arterial pulsation }\end{array}$ & $\begin{array}{l}\text { Surgical } \\
\text { Exploration }\end{array}$ & $\begin{array}{l}\text { Resection, saphenous } \\
\text { vein and dacron graft }\end{array}$ & No & [15] \\
\hline $\begin{array}{l}\text { Humerus } \\
\text { fracture }\end{array}$ & M/66 & $\begin{array}{l}2 \text { months after } \\
\text { immobilization }\end{array}$ & Massively edematous & Arteriography & Shoulder disarticulation & No & [16] \\
\hline $\begin{array}{l}\text { Supracondylar } \\
\text { fracture }\end{array}$ & $M / 3$ & $\begin{array}{l}7 \text { months } \\
\text { after surgery }\end{array}$ & $\begin{array}{l}\text { Slowly growing } \\
\text { painless mass }\end{array}$ & $\begin{array}{l}\text { Brachial } \\
\text { angiography }\end{array}$ & $\begin{array}{l}\text { Resection and } \\
\text { primary repair }\end{array}$ & No & {$[17]$} \\
\hline $\begin{array}{l}\text { latrogenic } \\
\text { injury }\end{array}$ & $M / 56$ & $\begin{array}{l}1 \text { month after } \\
\text { venepuncture }\end{array}$ & $\begin{array}{l}\text { Tender, warm, } \\
\text { nonpulsatile browny } \\
\text { erythematous swelling }\end{array}$ & Arteriography & $\begin{array}{l}\text { Resection and } \\
\text { primary repair }\end{array}$ & No & [18] \\
\hline Blunt trauma & $\mathrm{F} / 79$ & $\begin{array}{l}16 \text { months after } \\
\text { closed reduction }\end{array}$ & Pain, large lump & $\begin{array}{l}\text { Duplex } \\
\text { ultrasonography }\end{array}$ & $\begin{array}{l}\text { Resection and } \\
\text { arteriorrhaphy }\end{array}$ & No & [19] \\
\hline Drug abuse & M.F/32-52 & 1 day to 4 years & $\begin{array}{l}\text { Bleeding hematoma, } \\
\text { Painful swelling, } \\
\text { Median nerve palsy }\end{array}$ & Duplex Scan & $\begin{array}{l}\text { Resection and Primary } \\
\text { repair, Resection and } \\
\text { saphenous vein graft }\end{array}$ & No & [20] \\
\hline Missile injury & $M / 14$ & 2 weeks & Tender swelling & $\mathrm{CT}$ angiography & $\begin{array}{l}\text { Resection and GoreTex } \\
\text { patching }\end{array}$ & No & [21] \\
\hline
\end{tabular}

Abbreviations: N/A Not available, IUP Intrauterine pregnancy. 
instead of excision and intervening vascular grafting or bypass grafting after ligation of the brachial artery. Resection and primary repair is one of the usual treatment of brachial artery pseudoaneurysm that is incurred from trauma as shown in Table 1. There was no impairment of the distal circulation and no recurrence of the pseudoaneurysm during the postoperative follow-up period. The nonrecurrence is likely due to the removal of the adhesions around the neurovascular bundle when excising the pseudoaneurysm. However, as adhesion-induced nervevessel damage can occur later, a close follow-up is required.

\section{Conclusions}

Delayed rupture of a brachial artery pseudoaneurysm during rehabilitation therapy in a patient with postburn wound reconstruction of the upper extremity is very rare. Nerve-vessel damage may occur in such cases due to adhesion of neurovascular bundle to the surrounding tissues during burn rehabilitation. The exposed neurovascular bundle after fasciotomy in a severe burn patient should be covered with well vascularized soft tissue padding to prevent scarring to the surrounding tissue to prevent scar tethering-induced pseudoaneurysm formation. Although it is hard to observe symptoms of a pseudoaneurysm due to the fibrotic, hard reconstructed tissues, early diagnosis and immediate treatment of the pseudoaneurysm are needed to prevent serious complications, such as distal necrosis.

\section{Consent}

Written informed consent was obtained from the patient for publication of this case report and accompanying images.

\section{Competing interests}

The authors declare that they have no competing interests.

\section{Authors' contributions}

All of the authors were involved in the preparation of this manuscript. JYL wrote the manuscript and reviewed the literatures. HKim was an assistant surgeon and helped in literature search. HKwon participated in the clinica and surgical management. S-NJ participated in the conception, design of the study, and operated the patient. All authors read and approved the final manuscript.

Received: 11 April 2013 Accepted: 7 June 2013

Published: 13 June 2013

\section{References}

1. Jack L, Cronenwett KWJ: Cronenwett: Rutherford's vascular surgery. 7th edition. Saunders: Elsevier; 2010

2. Hudorovic N, Lovricevic I, Franjic DB, Brkic P, Tomas D: True aneurysm of brachial artery. Wien Klin Wochenschr 2010, 122:588-591.

3. Lie JT, Hayes CW, Feintuch TA: Congenital brachial artery aneurysm in an infant-a case report. Angiology 1988, 39:40-44.

4. Sayin AG, Bozkurt AK, Cangel U, Koksal C, Oz B: A brachial aneurysm in childhood caused by Ehlers-Danlos syndrome. J Cardiovasc Surg 2001, 42:687-689.
5. Godwin SC, Shawker T, Chang B, Kaler SG: Brachial artery aneurysms in Menkes disease. J Pediatr 2006, 149:412-415.

6. Hurwitz A, Arst DB: Mycotic aneurysm of the brachial artery after cure of bacterial endocarditis; successful treatment by surgical excision. $N$ Engl J Med 1948, 238:903-905.

7. Eshaghy B, Scanlon PJ, Amirparviz F, Moran JM, Erkman-Balis B, Gunnar RM: Mycotic aneurysm of brachial artery. A complication of retrograde catheterization. JAMA 1974, 228:1574-1575.

8. Chamberlain JL 3rd, Perry LW: Infantile periarteritis nodosa with coronary and brachial aneurysms: a case diagnosed during life. J Pediatr 1971, 78:1039-1042

9. Holleman JH Jr, Martin BF, Parker JH Jr: Giant cell arteritis causing brachial artery aneurysm in an eight-year-old child. J Miss State Med Assoc 1983, 24:327-328.

10. Aggarwal A, Dabadghao S, Roy S, Agarwal S, Misra R: Brachial artery aneurysm and peripheral gangrene in a patient with Behcet disease. Clin Exp Rheumatol 1993, 11:579-580.

11. Sarkar R, Coran AG, Cilley RE, Lindenauer SM, Stanley JC: Arterial aneurysms in children: clinicopathologic classification. J Vasc Surg 1991, 13:47-56. discussion 56-47.

12. Tidwell C, Copas P: Brachial artery rupture complicating a pregnancy with neurofibromatosis: a case report. Am J Obstet Gynecol 1998, 179:832-834.

13. Villanueva-Garcia E, Bas-Hermida P, Espinosa-Lledo C: Pseudoaneurysm of the brachial artery caused by an osteochondroma. A report of two cases. Int Orthop 1995, 19:248-250.

14. McBurney RP, Lee L, Feild JR: Thrombosis and aneurysm of the brachial artery secondary to brachial arteriography. Am Surg 1973, 39:115-117.

15. Thomas JM, Deshmukh N: Aneurysm of the brachial artery with complete thrombosis caused by a crutch. Am Surg 1973, 39:389-390.

16. Dolibois JM, Matrka PJ: False aneurysm of the brachial artery complicating closed fracture of the humerus. A case report. Clin Orthop Relat Res 1975, 113:150-153.

17. Asavamongkolkul A, Ruangsetakit C: False aneurysm of the brachial artery in supracondylar fracture treated with Kirschner wire fixation: a case report. Injury 2001, 32:256-257.

18. Coen LD, Johnson BF, Moorhead PJ, Raftery AT: False aneurysm of the brachial artery: an unusual complication following accidental puncture by a patient on home haemodialysis. Br J Clin Pract 1990, 44:202-203.

19. Crawford DL, Yuschak JV, McCombs PR: Pseudoaneurysm of the brachial artery from blunt trauma. J Trauma 1997, 42:327-329.

20. Siu WT, Yau KK, Cheung HY, Law BK, Tang CN, Yang GP, Li MK: Management of brachial artery pseudoaneurysms secondary to drug abuse. Ann Vasc Surg 2005, 19:657-661.

21. Naraynsingh V, Ramdass MJ: Missile injury by a weed wacker resulting in a false aneurysm of the brachial artery. The open cardiovascular medicine journal 2011, 5:218-219.

22. Habermann ET, Cabot WD: Median nerve compression secondary to false aneurysm of the brachial artery. Bull Hosp Joint Dis 1974, 35:158-161.

23. Ho PK, Weiland AJ, McClinton MA, Wilgis EF: Aneurysms of the upper extremity. The Journal of hand surgery 1987, 12:39-46.

24. Pelaz Esteban M, Beltran de Otalora S, Landeras RM, Gallardo E, Fernandez Echevarria MA, Perez Aguilar D: Posttraumatic pseudoaneurysm of the brachial artery and postsurgical retraction of median nerve: description of a case and ultrasonography findings. Emerg Radiol 2007, 13:269-272.

25. Yetkin U, Gurbuz A: Post-traumatic pseudoaneurysm of the brachial artery and its surgical treatment. Texas Heart Institute journal/from the Texas Heart Institute of St Luke's Episcopal Hospital, Texas Children's Hospital 2003, 30:293-297.

26. Morgan R, Belli AM: Current treatment methods for postcatheterization pseudoaneurysms. Journal of vascular and interventional radiology: JVIR 2003, 14:697-710.

27. Pages ON, Alicchio F, Keren B, Diallo S, Lefebvre F, Valla JS, Poli-Merol ML: Management of brachial artery aneurisms in infants. Pediatr Surg Int 2008, 24:509-513.

28. Parodi JC, Schonholz C, Ferreira LM, Bergan J: Endovascular stent-graft treatment of traumatic arterial lesions. Ann Vasc Surg 1999, 13:121-129.

29. Kurimoto Y, Tsuchida Y, Saito J, Yama N, Narimatsu E, Asai Y: Emergency endovascular stent-grafting for infected pseudoaneurysm of brachial artery. Infection 2003, 31:186-188. 
30. Fellmeth BD, Roberts $A C$, Bookstein JJ, Freischlag JA, Forsythe JR, Buckner NK, Hye RJ: Postangiographic femoral artery injuries: nonsurgical repair with US-guided compression. Radiology 1991, 178:671-675.

31. Kehoe ME: US-guided compression repair of a pseudoaneurysm in the brachial artery. Radiology 1992, 182:896

32. Sheiman RG, Brophy DP, Perry $L$, Akbari C: Thrombin injection for the repair of brachial artery pseudoaneurysms. AJR Am J Roentgenol 1999, 173:1029-1030.

33. Owen RJ, Haslam PJ, Elliott ST, Rose JD, Loose HW: Percutaneous ablation of peripheral pseudoaneurysms using thrombin: a simple and effective solution. Cardiovasc Interv Radiol 2000, 23:441-446.

34. O'Neill S, O'Donnell ME, Collins A, Harkin DW: Brachial artery aneurysm following open repair of posttraumatic false aneurysm and arteriovenous fistula. Vasc Endovasc Surg 2010, 44:691-692.

35. Noaman HH: Microsurgical reconstruction of brachial artery injuries in displaced supracondylar fracture humerus in children. Microsurgery 2006, 26:498-505.

doi:10.1186/1749-7922-8-21

Cite this article as: Lee et al: Delayed rupture of a pseudoaneurysm in the brachial artery of a burn reconstruction patient. World Journal of

Emergency Surgery 2013 8:21.

\section{Submit your next manuscript to BioMed Central and take full advantage of:}

- Convenient online submission

- Thorough peer review

- No space constraints or color figure charges

- Immediate publication on acceptance

- Inclusion in PubMed, CAS, Scopus and Google Scholar

- Research which is freely available for redistribution 